\title{
A Discussion on the Class Refinement Management Mode of China's Higher Education
}

\author{
Z.X Pang \& X. Wang \\ China University of Petroleum, Beijing, China
}

\begin{abstract}
Along with the development of Chinese higher education, some ideas and methods of the refinement management have been introduced to students' work in college. The development of the refinement management mode is an important step to promote the connotation construction of colleges and universities and apply the 'Scientific Outlook on Development' in Chinese higher education. This paper starts from seeking the origin and the connotation of refinement management to discussing the specific measures of implementing it. Finally, it talks about the prospect of the refinement management in higher education.
\end{abstract}

KEYWORD: Higher education; Refinement management; Management measures; Management mode

\section{INTRODUCTION}

\subsection{The role of class refinement management}

The class is the basic component in China universities and a powerful platform where students can help and learn from each other. By conducting many class activities with various forms and rich contents, these activities are good for the class organization and management, students' education, uniting classmates and so on. All of these have proved that the class plays a key role in college students' ideological and political education (Han and $\mathrm{Li}, 2008$; $\mathrm{Ma}$ and $\mathrm{Li}, 2011$ ). Due to number of college students extremely rising, the ideological and political education is difficult for teachers and administrators. Therefore, in Chinese universities, the class refinement management gradually becomes important more and more for the college students' ideological and political education work. As practice has shown, the refinement management introduced to the class construction will play a major role in promoting the growth of the students.

\subsection{The origin of class refinement management}

The refinement management was a kind of enterprise management belief that came from Japan in the 1950's, including achieving refinement in division of labor in society and quality of service. And the class refinement management is an innovative practice, which refers to applying the elaborating management theory in school, especially in college where the talent is widely distributed. For contemporary college students, the refinement management of class provides a good and unique approach for college students' education work, which is created during the practice of self promoting the harmonious relationship between teachers and students (Xiang, 2008; Liu, 2012; Zeng, 2013).

With a boom of our social economy, our state's higher education has gradually changed from elite education to mass education. Among thousands of colleges and universities in China, how to find an efficient, safe and harmonious education concept has become an urgent problem. If colleges tend to take the path to develop the harmonious and efficient management, they must focus on the quality of management. Therefore, the refinement management has gradually become a characteristic brand in the management of colleges and universities nowadays.

\section{AN EXHAUSTIVE COMPREHENSION ABOUT CLASS REFINEMENT MANAGEMENT}

The class refinement management will be realized under a scientific and systematic management system guiding. Its essence is to highlight two aspects, such as 'delicacy' and 'chariness', to consolidate the class culture construction and advocate the innovation management service mode. The methods can create a good class atmosphere. Well-known universities such as Harvard, Oxford and Peking University, have formed their own 
campus cultural consciousness and characteristics, and also established their own class culture. Under the guideline of this class culture, they have achieved outstanding results in all aspects, such as education, teaching, scientific research, administration and so on. (Li, 2006; Xiang, 2008; Liu, 2012).

The class refinement must persist in the base of students to reach the effective management with delicate attitude and careful way. Therefore, the connotation of class refinement management should include the two followings.

The first comprehension can be expressed as 'delicacy'. Class activities should be practical and scientific, which starts from the fundamental interests of students and provides a real help for students. For some important jobs from our university, we should take delicate measures to achieve considerable effects.

The second comprehension can be expressed as 'chariness'. The class management measures must be systematic and meticulous. By formulating a set of systematic and meticulous rules, we can serve the students better and help them grow faster.

\section{THE MEASURES OF CLASS REFINEMENT MANAGEMENT}

\subsection{Respecting the student's differences and excavating their development potential}

College is a new starting point in our lives. College students who are standing on the starting line are full of ideal and hope for the future. But their ideal, faith, IQ and EQ are different each other, so we can't hold the same view for all the students. What we should do is not to find their shortcomings, but to lead them out of misunderstanding and help them correcting their own shortcomings. As the saying goes, 'Foster strengths and circumvent weaknesses' (Li, 2006; Zeng, 2007).

College students are in the life transition, with their own growth and knowledge development during learning processes. There will be varieties of problems for them, so what students need is such a guide to solve the problems. We should learn to tolerate students, using broad mind and kind heart to influence students. Parents send their children to university in order to make them larger progress. Under the education and management from counselors or teachers, we should help them to finish their lives smoothly in college. 'Differential treatment in education', that is, a different management method should be employed for every student in refinement management. We should have the specific command and the accurate information of each student. Based on the college's students, we need to be aware of the change of role to become a real player in the class activities, not just taking part in the arrangement.

\subsection{A walk in my shoes, pass love and care}

Implementing the class refinement management is like the spring rain soaking into the soil. The key of communication with students is to motivate their own feelings. So we have to put ourselves in their shoes to achieve emotional resonance with them. Firstly, in order to achieve the best communication with the students, we should walk into the students' emotion world and become their mind friends. We should learn to consider problem and experience lives from their views. Secondly, we should often go to student's dormitory, which is home for their living and studying. In their homes, we can talk with them about all aspects of lives. We are supposed to be easy-going to let them take us as a family. Thirdly, in the class refinement management, as a part-time instructor, we should play a leading role, which means that we should take anything seriously, such as work, study and students. And we should also love students by heartily. Only by our love, can we win the respect of them.

\subsection{Clearing the responsibility to realize the standardization of students' management}

Counselors or teachers should take daily record of students' situations and classify them according to their thoughts and behaviors, which is called 'teaching students in accordance with their aptitude'. Through the class meeting, visiting the dormitory and the network platform, counselors or teachers can communicate with students to master their dynamics, communicate emotion and help students to understand and deal with the confusion and difficulties. Through the class evaluation, departments can restrain students' thought and behavior, environmental hygiene, discipline, extracurricular activities, the management of security and stability, civilization etiquette, etc. The results of evaluation will be checked every day, summarized every week and publicly displayed every month. These series of methods can effectively train students' good custom to do anything but not take anything slightly.

To realize the standardization of the student management, the first thing is to carry out the responsibility and make it clear. In the student management of colleges and universities, the main staffs include counselors, teachers, student union and youth league committee management team. So clearing the responsibility of student management workers is to clear the counselors', the teachers', the student union's or youth league committee's responsibility, making sure each specific position requirements. For instructors, the division of labor 
responsibility system should be adopted basing on the class management. According to counselors' different characteristics and special skills, they are responsible for different job of the student management. The method not only exercises instructors, but also embodies the democratic participation. Not only it arouses the enthusiasm of the counselor work, but also enhances their sense of responsibility.

\section{THE SIGNIFICANCE OF CLASS REFINEMENT MANAGEMENT}

\subsection{Class refinement management is benefit for achieving the integration of high quality resources}

At present, the main contradiction of education is, on the one hand, the growing demand for high quality education resources. On the other hand, the high quality education resources are relatively scarce in China (Feng, 2011). If you want to solve this contradiction, you must expand high quality resources. Except increasing education investment, the other works including strengthening management to improve students' quality and improving management level of ascension to promote the optimization of teaching quality are also needed. Make sure that every college all becomes the sources to provide the high quality graduates. Refinement management in student management pays attention to every detail of every person and every object in campus, which is providing more possibility of achieving this goal.

\subsection{Class refinement management is benefit for constructing a reasonable management mode}

The school is a place of imparting knowledge and educating students, which should be open to the entire school students and focus on the students' comprehensive ability development. In order to achieve whole opening to all students, we must understand each student's characteristic, such as psychology, physiology or learning. We can not discard anyone among the students. We should cultivate overall qualities with full development of morality, wisdom, physique and aesthetic to promote the development of the students' comprehensive ability. Each aspect contains many details, but any one can't be ignored. The average age of undergraduates is 22 or so. They are entirely unsophisticated with few social experiences, and their psychological endurance is poorer, which means they are easy to get hurt. So they need more society protection, especially the protection from the school. Obviously, the past extensive student management mode had been unable to meet the current requirements. The refinement management is imperative in college education nowdays.

\subsection{The refinement management is benefit for education concept of conversion}

In the new stage of education reform, our educators have deep considered and recognized the traditional education from its concept to the ways. Then they set up the new education idea. First of all, we are going to change from the past idea to the new education idea, that is, we put too much emphasis on teaching for the social service in past but now we promote the development of society and human to let the students get lifelong learning ability, innovation ability and survival ability in vocational education. On the quality of education, we must not only emphasize the initiative and enthusiasm in the learning process, but also pay attention to cultivate students' ability of independent thinking, as well as the ability to analyze, judge and deal with the problems, to improve the students' all-round comprehensive ability (Meng, 2010).

Only by realizing the refinement management, can we adapt to these new forms to develop new type of education mode and deep promote education reform.

\section{AN OUTLOOK ON CLASS REFINEMENT MANAGEMENT}

As a kind of new class management concept, the class refinement management provides a way to strengthen the class management and improve the relationship between teachers and students. The concept is innovative, scientific and practical to improve class management system. It can also be good for digging the innovative talents and promoting the education development. In the next few decades, the concept will be practiced constantly with the development of times. And the concept will keep gradually improving and growing. In a word, the class refinement management is a direction of our efforts, and must be combined with the actual conditions of Chinese college students. We should focus on the students' features and promote development with continuous practice. Only in this way, our students and our class will be more energetic and more harmonious.

\section{CONCLUSIONS}

Class refinement management is a scientific and systematic system. Its essence is to highlight two aspects of class culture construction, such as 'delicacy' and 'chariness'. Therefore, the system can 
promote the innovation management service mode and create a good class atmosphere.

The measures of class refinement management mainly include: Firstly, we should respect the students' differences to excavate students sdevelopment potential; Secondly, we should achieve the best communication with students to motivate their inner feelings; Thirdly, we should clear the management responsibility to realize the standardization in the students' daily management.

The significance of the refinement management include: firstly, class refinement management is benefit for achieving the integration of high quality resources; Secondly, class refinement management is benefit for constructing a reasonable management mode; Thirdly, class refinement management is benefit for education concept of conversion.

\section{REFERENCES}

[1] R.B. Ma, Y.L. Li. Theory and Practice of the Class Refinement Management, China Educational Technology \& Equipment, 2011, 11:73-74 (in Chinese).
[2] G.J. Han, Z.F. Li. The Apply of the Class Refinement Management in School Management. Vocational and Technical Education. 2008, 23:82-82 (in Chinese).

[3] Z. Zeng. Vocational Student Work Refinement Management Exploration, Journal of Hubei Three Gorges Polytechnic, 2013, 1(10):49-57 (in Chinese).

[4] H.P. Liu. Strengthen the Class Refinement Management Promote the Healthy Development of Students, Yunnan Education, 2012, 1:39-39 (in Chinese).

[5] B.C. Xiang. The Exploration of Applying the Class Refinement Management in School. Cutting Edge Education. 2008, 8:29-29 (in Chinese).

[6] X.Z. Li. 'Unique Insight'--- Four Kinds of Quality that Teacher in Charge should have. Journal of Hebei Tourism Vocational College. 2006, 4:84-85 (in Chinese).

[7] S.L. Zeng. The Class Management Work Should not Use "Agent". The Science Education Article Collects. 2007, 11:27-27 (in Chinese).

[8] Y.Q. Feng. How the Teacher in Charge to do Class Management Well. Popular Science. 2011, 5:148-148 (in Chinese).

[9] H.Y. Meng. How to Guide Parents to Participate in Class Management. Guangxi Journal of Light Industry. 2010, 19:38-38 (in Chinese). 